\title{
Rapid and sensitive determination of cobalt by adsorptive cathodic stripping voltammetry using tin-bismuth alloy electrode
}

\author{
Li Zhang ${ }^{1} \cdot$ Da-wei Pan $^{2} \cdot$ Yang-sheng Liu ${ }^{1}$
}

Received: 12 August 2015 / Revised: 4 November 2015 / Accepted: 5 November 2015 / Published online: 20 November 2015

(C) Springer-Verlag Berlin Heidelberg 2015

\begin{abstract}
Tin-bismuth alloy electrode ( $\mathrm{SnBiE}$ ) was used for trace cobalt determination for the first time. Compared to the bismuth bulk electrode, the $\mathrm{SnBiE}$ possesses the advantages of higher hydrogen overpotential, easier manufacture, and lower cost. In addition, there is no need for a pretreatment (in terms of modification) of the electrode before measurements. The analysis of Co(II) was made by the adsorptive accumulation of the cobalt-nioxime complex from solution containing $60 \mu \mathrm{M}$ nioxime and $0.1 \mathrm{M}$ ammonia at $\mathrm{pH} 9.4$ and followed by the reduction of the accumulated complex. The electroanalysis results show that the optimal sensitivity can be obtained by using nitrite as the auxiliary reagent. The calibration plot for $\mathrm{Co}$ (II) quantification was linear from 0.2 to $20 \mathrm{nM}$ with a correlation coefficient of 0.998 . Meanwhile, a detection limit of $44 \mathrm{pM}$ was obtained in connection with an accumulation time of $60 \mathrm{~s}$, which is more sensitive than that of the mercury, bismuth, lead, and lead-copper electrodes. The practical applications of $\mathrm{SnBiE}$ have been performed for the determination of $\mathrm{Co}$ (II) in real water samples, and the results are consistent with those results by use of inductively coupled plasma-mass spectrometry (ICP-MS).
\end{abstract}

Keywords Tin-bismuth alloy electrode $\cdot$ Adsorptive cathodic stripping voltammetry $\cdot$ Cobalt $\cdot$ Tap water

Yang-sheng Liu

yshliu@pku.edu.cn

1 College of Environmental Sciences and Engineering, Peking University, Beijing 100871, China

2 CAS and Shandong Provincial Key Laboratory of Coastal Zone Environmental Processes, Yantai Institute of Coastal Zone Research, Chinese Academy of Sciences, Yantai 264003, China

\section{Introduction}

The determination of trace amounts of cobalt in natural waters is of great interest because the cobalt, as a major constituent of vitamin, is important for humans and other living organisms. In addition, cobalt- 60 , a radioactive isotope of cobalt, is an important source of gamma rays which is often used for treating some cancer or as a medical tracer. However, toxic effects of the excess cobalt have been found, which include polycythemia, skin allergies, pulmonary disorders, and other adverse reactions [1]. In 1998, the European Union identified the cobalt chloride as a carcinogen in the second category. The production and usage of blue silica gel which contains cobalt chloride has been banned in Europe and the USA. The water contaminated by cobalt became a big threat to not only the ecological environment system but also the human health. Hence, monitoring and determination of cobalt is highly urgent in many fields, especially in water system.

The determination of cobalt in water samples often requires sensitive methods and portable instrument, because cobalt is often at a low concentration $[2,3]$. However, the common methods including chemiluminescence detection [4], electrothermal atomic absorption spectrometry [5], flame atomic absorption spectrometry [6], graphite furnace atomic absorption spectrometry (GFAAS) [7], and microwave plasma torchatomic emission spectrometry [8] often do not have enough sensitivity, selectivity, and freedom from matrix interferences. These methods must combine with pretreated procedures. In contrast, the electrochemical stripping analysis has been recognized as a typical approach for trace metal ion measurement because it combines the advantages of the high speed, high sensitivity, simple equipment requirements, as well as low expenditure for tests and maintenance. Besides, it also supplies a possibility of constructing useful and portable apparatuses for on-site environmental monitoring. 
Unlike the anodic stripping voltammetry (ASV), the adsorptive cathodic stripping voltammetry (AdCSV) has often been used for the determination of trace amounts of $\mathrm{Co}, \mathrm{Ni}$, and $\mathrm{Cr}$ which can neither form amalgams with mercury nor form metal membrane in the inert metal electrodes. The AdCSV determination usually involves the formation of metal complexes and an accumulation on the working electrodes and then the subsequent measurement of the reduction or oxidation peak of the accumulated complex of the electrode surface. Various complex agents have been used to determine the cobalt including dimethylglyoxime (DMG) [9-11], nioxime [12-15], $\alpha$-furil dioxime [2], and pyrogallol red [16]. Among them, DMG and nioxime are the most popular complex agents because they offer the higher selectivity, the better shape of voltammetric signal, and the more excellent sensitivity.

The proper choice of the working electrode is very important for the electrochemical analysis. The mercury $(\mathrm{Hg})$ electrodes not only have a highly reproducible and easily renewable surface but also have a high hydrogen overvoltage [17]. However, its use has been banned in many countries due to its hyper-toxicity. In last decades, various electrodes have been investigated for substituting $\mathrm{Hg}$ electrode, such as glassy carbon electrode, graphite electrode, gold electrode, silver electrode, and iridium electrode. But none of these electrodes has been found to be acceptable for their relatively low hydrogen overvoltage (usually below $-0.8 \mathrm{~V}$ [18]), large background current, or poor precision and resolution [19].

In 2000, bismuth-based electrodes were introduced as a favorable alternative mercury-free electrode for stripping voltammetry analysis of trace metals [20]. It offers the closest behavior to mercury but with very low toxicity. Both in situ or ex situ bismuth film electrode [21, 22], bismuth bulk electrode (BiBE) [23, 24], and tin-bismuth film electrode [25] display an attractive stripping behavior. However, the bismuth bulk electrode is complicated to be fabricated due to the fragileness of the bismuth. For the bismuth film and tinbismuth film electrode, when they are used in AdSV analysis where alkaline solutions are typical supporting electrolytes, it is inconvenient because of the risk of hydrolysis of $\mathrm{Bi}^{3+}$ species $[23,26]$ which limits its practical applications. Then, some concerns were focused on lead film electrode [27-29] and lead-copper film electrode [30]. Lead can be stabilized easily at mild alkaline $\mathrm{pH}$, but it is widely known as a toxic metal. In addition, the preparation of those modified film electrodes is complex, which make the electrodes lack of consistency and mechanical strength. Considering both the advantages and disadvantages of aforementioned electrodes, the tinbismuth alloy electrode $(\mathrm{SnBiE})$, which has been proposed in our work [31-33], is used in AdCSV determination of cobalt in this paper. This new $\mathrm{SnBiE}$ based on the tin-bismuth alloy is of little environmental damage, and it is conveniently fabricated and used. Besides, it possesses a high hydrogen overvoltage which expands the scope and applicability of electrochemical technique for the determination of metal ions at negative potentials [33].

Here, in this work, for the first time, SnBiE was successfully used for the detection of trace amount of cobalt ions in the presence of nitrite in combination with an adsorptive cathodic stripping voltammetry. Nioxime acts as a complexing agent. It was found that the optimal sensitivity can be achieved by using nitrite as the auxiliary reagent, which allows a detection limit of sub-nanomolar level without any deoxygenating or electro-plating pretreatment. A comparison of the applicable potential windows was conducted at the same $\mathrm{pH}$ between the BiBE and the SnBiE. In addition, the compositions of the supporting electrolyte and the analytical parameters (i.e., deposition time and deposition potential) have been optimized. Based on the established method, the practical applications have been carried out for the determination of $\mathrm{Co}^{2+}$ in tap water samples.

\section{Experimental}

\section{Reagents}

$\mathrm{Sn}-\mathrm{Bi}$ alloy wires ( $\mathrm{Sn}: \mathrm{Bi}, 42: 58 \mathrm{wt} \%, 1 \mathrm{~mm}$ in diameter) were purchased from KAIT Electronic Material Co., Ltd., Guangzhou, China. A stock solution of cobalt(II) was prepared by dilution of the National Standard Substances of Cobalt (GBW(E)081005, $1 \mathrm{mg} / \mathrm{mL}$ ), acidified to $\mathrm{pH}$ of 2.0 with distilled $\mathrm{HCl}$, and then diluted to various concentrations of working solutions. An aqueous stock solution of $0.05 \mathrm{M}$ nioxime (1,2-cyclohexanedione dioxime) was prepared by dissolving the appropriate amount in $0.2 \mathrm{M}$ sodium hydroxide. A $0.1 \mathrm{M}$ dimethylglyoxime was prepared by diluted into absolute ethyl alcohol, and $0.5 \mathrm{M}$ sodium nitrite was prepared by diluted into ultrapure water. All of those solutions were prepared weekly. 0.1 M ammonia buffer solution ( $\mathrm{pH} 9.4$ ) prepared with ammonium chloride and ammonia was used as the supporting buffer solution for $\mathrm{Co}^{2+}$ determination. All other chemicals were analytical reagents and used without further purification. Ultrapure water $(18.2 \mathrm{M} \Omega \mathrm{cm}$ specific resistance) obtained from a Pall Cascada laboratory water system was used throughout the experiments. All of electrochemical experiments were carried out at room temperature and under a non-deoxygenating condition.

\section{Apparatus}

All electrochemical experiments were carried out in a conventional three-electrode cell controlled by a CHI 660D Electrochemical Work Station (CH Instruments, Inc.). A SnBi alloy disk electrode ( $\mathrm{SnBiE}$ ) was used as the working electrode. A platinum foil was applied as the counter electrode, and a saturated calomel electrode (SCE) served as the 
reference electrode. The $\mathrm{SnBiE}$ was fabricated with a $\mathrm{Sn}-\mathrm{Bi}$ alloy wire ( $2 \mathrm{~cm}$ in length, $1 \mathrm{~mm}$ in diameter) which was conducted with a copper wire and encapsulated in Teflon to make a disc electrode. The $\mathrm{pH}$ measurements were performed at an E-201-C model pH meter (Shanghai Leici Instrument Factory). Inductively coupled plasma-mass spectrometry (ICP-MS) was measured with an ELAN DRC II inductive coupling plasma-mass spectrometer (Perkin Elmer Ltd., Hong Kong).

\section{Analytical procedure}

The analysis of $\mathrm{Co}^{2+}$ was performed in a $25-\mathrm{mL}$ beaker containing $20 \mathrm{~mL} 0.1 \mathrm{M}$ ammonia buffer solution without removal of oxygen. Prior to analysis, the $\mathrm{SnBiE}$ was polished with a $\# 2500$ silicon carbide abrasive paper for a smooth and bright surface, and it did not need any activation. For $\mathrm{Co}^{2+}$ determination, the accumulation of $\mathrm{Co}^{2+}$ was carried out at $-1.0 \mathrm{~V}$ (vs SCE) under stirring with an accumulation time of $60 \mathrm{~s}$. The stripping voltammogram was then recorded in quiescent solution from -1.0 to $-1.2 \mathrm{~V}$ (vs SCE) after a 10 -s quiescence period.

Parameters of DP-AdCSV were as follows: step increment, $4 \mathrm{mV}$; pulse amplitude, $50 \mathrm{mV}$; pulse width, $0.025 \mathrm{~s}$; sample width, $0.0167 \mathrm{~s}$; pulse period, $0.05 \mathrm{~s}$.

\section{Results and discussion}

\section{The potential window of the $\mathrm{SnBiE}$}

A comparison of the applicable potential windows was conducted between the $\mathrm{SnBiE}$ and bismuth bulk electrode (BiBE) in $0.1 \mathrm{M}$ ammonia buffer ( $\mathrm{pH}$ 9.4) (Fig. 1). As shown in Fig. 1, the BiBE exhibits a relatively limited hydrogen overvoltage (in the vicinity of $-1.40 \mathrm{~V}$ ) but a wide anodic range (up to $-0.40 \mathrm{~V}$ ) with an applicable potential window of $1.00 \mathrm{~V}$, which is in good agreement with the behavior observed by Joseph Wang [34] and A. Economou [35]. Compared to the $\mathrm{BiBE}$, a wider cathodic potential range of $\mathrm{SnBiE}$ is found up to $-1.60 \mathrm{~V}$, though a limit of anodic potential region is found to be around $-0.85 \mathrm{~V}$ due to the oxidation of Sn. Therefore, SnBiE with an applicable negative potential window of up to $-1.60 \mathrm{~V}$ possesses a higher hydrogen overpotential than the BiBE, which indicates that it is extremely suitable for the adsorptive cathodic stripping voltammetry (AdCSV).

\section{Enhancement effect of nitrite on the Co(II)-nioxime}

In this work, the catalytic effect of nitrite ions was studied on the $\mathrm{Co}(\mathrm{II})$-nioxime cyclic voltammetric response at the SnBiE. Cyclic voltammograms after the

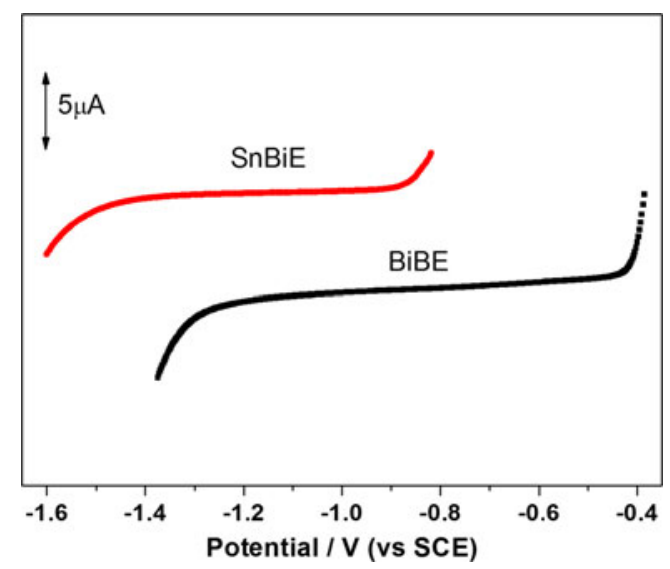

Fig. 1 The accessible potential windows of BiBE (black line) and $\mathrm{SnBiE}$ (red line) in $0.1 \mathrm{~mol} / \mathrm{L}$ ammonia buffer solution ( $\mathrm{pH} 9.4)$. Linear sweep voltammetry; scan rate, $100 \mathrm{mV} / \mathrm{s}$

addition of nioxime and nitrite in $0.1 \mathrm{M}$ ammonia buffer ( $\mathrm{pH}$ 9.4) containing $0.2 \mu \mathrm{M} \mathrm{Co}(\mathrm{II})$ were recorded (Fig. 2). As can be seen from Fig. 2, in the potential range from -1.3 to $-1.0 \mathrm{~V}$, the cyclic voltammograms show that there is a low background current and no redox peak with the addition of $0.2 \mu \mathrm{M} \mathrm{Co}^{2+}$ solution (curve a). After the introduction of nioxime into the solution, a $\mathrm{Co}(\mathrm{II})$ cathodic reduction peak becomes apparent as a result of adsorptive accumulation and further reduction of the $\mathrm{Co}(\mathrm{II})$-nioxime complex on the $\mathrm{SnBiE}$ surface (curve $\mathrm{b}, i_{p}=1.251 \times 10^{-6} \mathrm{~A}$ ). However, no oxidation peak was observed at $\mathrm{SnBiE}$ on the reverse scan of the cyclic voltammograms, which elucidated that the electrode reaction was an irreversible charge transfer process. The subsequent addition of nitrite ions caused an enhancement of the Co(II)-nioxime cyclic voltammetric response (curve c, $i_{p}=3.013 \times 10^{-6} \mathrm{~A}$ ), which is the result of catalytic reduction of nitrite ions. The SnBiE exhibits a well-defined electrochemical behavior in the negative potential region with low background and high electrochemical response, which demonstrates that the alloy electrode possesses good interfacial electrochemical characteristics and implies the possibility of voltammetric detection of $\mathrm{Co}^{2+}$ on this SnBiE.

The mechanism for adsorption cathodic stripping voltammetry of $\mathrm{Co}(\mathrm{II})$-nioxime complex on the $\mathrm{SnBiE}$ can be explained according to the $\mathrm{Hg}$ electrodes which was proposed by Andrzej Bobrowski et al. [36] and Marisol Vega et al. [12]:

Firstly, in the presence of nioxime, ammonia ions, and nitrite ions, the $\mathrm{Co}^{2+}$ is oxidized to $\mathrm{Co}^{3+}$ in the solution, and then it formed a complex of $\mathrm{Co}^{\mathrm{III}}$ (nioxime) ${ }_{2} \mathrm{NO}_{2} \mathrm{NH}_{3}$ near the electrode surface.

$\mathrm{Co}^{2+}+2$ nioxime $+\mathrm{NH}_{3}+\mathrm{NO}_{2}{ }^{-} \rightarrow \mathrm{Co}^{3+}($ nioxime $){ }_{2} \mathrm{NO}_{2} \mathrm{NH}_{3 \text { sol }}+\mathrm{e}^{-}$ 
Then, during the accumulation period at an accumulation potential of $-1.0 \mathrm{~V}$, the $\mathrm{Co}$ (III (nioxime) ${ }_{2} \mathrm{NO}_{2} \mathrm{NH}_{3}$ complex is absorbed onto the $\mathrm{SnBiE}$ surface.

$\mathrm{Co}^{3+}($ nioxime $){ }_{2} \mathrm{NO}_{2} \mathrm{NH}_{3 \text { sol }} \rightarrow \mathrm{Co}^{3+}($ nioxime $){ }_{2} \mathrm{NO}_{2} \mathrm{NH}_{3 \text { ads }}\left(\mathrm{E}_{\text {acc }}=-1.0 \mathrm{~V}\right)$
Finally, followed by a negative voltammetric scan, the $\mathrm{Co}{ }^{\mathrm{III}}$ (nioxime) ${ }_{2} \mathrm{NO}_{2} \mathrm{NH}_{3}$ complex was reduced to the $\mathrm{Co}$ (II) complex with a one-electron transfer process at $-1.128 \mathrm{~V}$. The reduced species desorb from the electrode surface, followed by diffusion into the double layer where it is reoxidized to Co(III) by nitrite. The reduction current is catalytically enhanced by the presence of nitrite, which is represented by the Eq. (3):

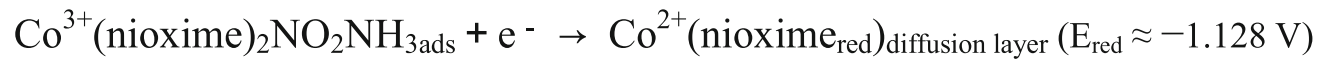

$$
\begin{aligned}
& \text { Catalytic cycle } \\
& \mathrm{NO}_{2}{ }^{-}
\end{aligned}
$$

\section{Optimization for determination of $\mathrm{Co}^{2+}$ at the $\mathrm{SnBiE}$}

\section{Comparison of different ligands}

Nioxime and DMG ligands are usually used in the determination of cobalt at different electrodes. Therefore, we mainly compared the two ligands to evaluate their sensitivity for cobalt. The ligand concentrations were changed to determine the optimal ligand concentration for maximum sensitivity in $0.1 \mathrm{M}$ ammonia buffer (pH 9.4) spiked with $2 \mathrm{nM}$ cobalt(II), and the adsorptive cathodic stripping voltammograms were recorded from -0.90 to $-1.20 \mathrm{~V}$ after a 60 -s adsorption at $-0.90 \mathrm{~V}$. The optimized concentration of the ligands was determined by the highest increase of peak current when equivalent ligand was added to the solution. A linear analysis was applied to detect the sensitivity of the ligands for the determination of cobalt. The optimum ligand concentration, the

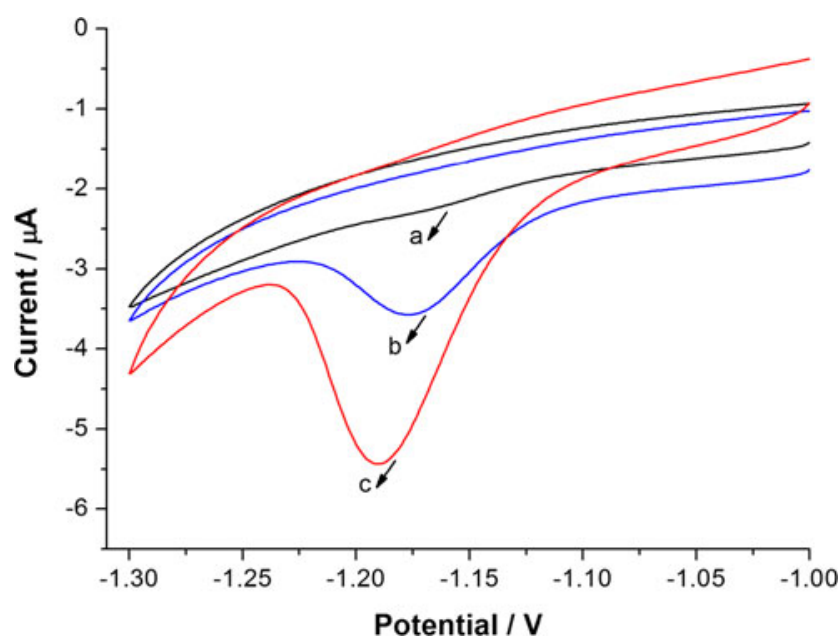

Fig. 2 Cyclic voltammograms at $\mathrm{SnBiE}$ in (a) $0.1 \mathrm{M}$ ammonia buffer solution (pH 9.4) containing $0.2 \mu \mathrm{M} \mathrm{Co}^{2+}$ ions, (b) as (a) $+200 \mu \mathrm{M}$ nioxime, and (c) as (a) $+200 \mu \mathrm{M}$ nioxime $+0.5 \mathrm{M}$ nitrite ions. Scan rate, $50 \mathrm{mV} / \mathrm{s}$ sensitivity, and the peak potential for each ligand test are listed in Table 1. As shown in Table 1, the sensitivity of nioxime was 126 times more than that of DMG, but the reagent consumption was only one fiftieth of that of DMG. The peak potential for cobalt in the presence of nioxime was slightly more positive than DMG. The largest sensitivity was obtained using nioxime, which had the highest sensitivity but with the less reagent consumption. Therefore, nioxime was selected as complex ligand.

\section{Effects of the solution composition}

Three buffer solutions including ammonia buffer, phosphate buffer, and borate buffer solution were chosen for study of their suitability for $\mathrm{Co}^{2+}$ determination at the $\mathrm{SnBiE}$. The voltammograms (not shown) indicated that the determination sensitivity was poor, and the catalytic effect was absent unless the ammonia buffer was present. Stable and sensitive signals were obtained for the ammonia buffer solution and it was, therefore, used in subsequent study. Furthermore, different concentrations of ammonia buffer solution, in the range of $0.01-$ $0.10 \mathrm{M}$, were tested at a constant concentration of $\mathrm{Co}^{2+}$ $(2 \mathrm{nM})$. The best performance can be obtained in $0.10 \mathrm{M}$ ammonia buffer solution due to its better current response. Therefore, $0.10 \mathrm{M}$ ammonia buffer solution was selected for further experiments.

\section{Effects of the nioxime concentration}

To determine the optimal ligand concentration for the maximum sensitivity, the effect of nioxime concentration was examined from 0 to $100 \mu \mathrm{M}$. Voltammograms were recorded from -0.90 to $-1.20 \mathrm{~V}$ after a 60 -s accumulation at $-0.90 \mathrm{~V}$ (Fig. 3a). Results showed that the peak current for cobalt increased rapidly with the increase of nioxime concentration up to $60 \mu \mathrm{M}$ and then increased slowly with the increase of nioxime concentration up to $100 \mu \mathrm{M}$ due to the achievement 
Table 1 Comparison of optimized conditions and sensitivity for the determination of cobalt using various ligands

\begin{tabular}{lccc}
\hline Ligand & $\begin{array}{l}\text { Optimum concentration } \\
(\mathrm{mol} / \mathrm{L})\end{array}$ & Sensitivity (A mol/L) & Peak potential (V) \\
\hline 1,2-cyclohexanedione (nioxime) & $6.25 \times 10^{-5}$ & $2.54 \times 10^{-3}$ & -1.080 \\
Dimethylglyoxime (DMG) & $3.00 \times 10^{-3}$ & $2.01 \times 10^{-5}$ & -1.092 \\
\hline
\end{tabular}

of the maximum coverage. The increase of the nioxime concentration also caused the appearance of a broad reduction peak at $-1.0 \mathrm{~V}$, which is presumably due to the reduction of the ligand. Therefore, an optimum nioxime concentration of $60 \mu \mathrm{M}$ was selected for further experiments.

\section{Effect of the nitrite concentration}

The peak current of cobalt-nioxime complex as a function of the auxiliary reagent (nitrite) concentration is displayed in Fig. $3 \mathrm{~b}$. The concentration of nitrite varies from 0 to $0.45 \mathrm{M}$. It can be found that the peak height for cobalt increases linearly with the nitrite concentration until the concentration is up to $0.3 \mathrm{M}$. Then, it levels off at higher concentrations. Meanwhile, the peak of cobalt was found to shift toward more negative potential as the nitrite concentration increased, which suggested that the formation of cobalt complexes was more stable. Therefore, $0.3 \mathrm{M}$ nitrite concentration was selected for further experiments.

\section{Effect of $p H$ values}

The effect of $\mathrm{pH}$ of the supporting electrolyte was studied by varying the $\mathrm{pH}$ in the range of 8.0 to 10.0 . The peak current of cobalt as a function of $\mathrm{pH}$ is shown in Fig. 4a. The best sensitivity of the electrode for the $\mathrm{Co}^{2+}$ measurement in the absence of interfering ions was obtained at $\mathrm{pH} 9.4$ because it produced maximum sensitivity for cobalt with small interference by the free nioxime. At $\mathrm{pH}$ lower than 9.4, the reduction peak of nioxime increased gradually as $\mathrm{pH}$ decreased which interfered with the stripping peak of $\mathrm{Co}^{2+}$. As for $\mathrm{pH}$ higher than 9.4, the response current decreased significantly, probably as a result of hydrolysis of cobalt ions at increasing $\mathrm{pH}$. Therefore, ammonia buffer solution with pH 9.4 was selected as the optimum experimental condition.

\section{Effect of accumulation potential}

The effect of accumulation potential on the stripping peak current of $2 \mathrm{nM} \mathrm{Co}^{2+}$ was examined over the potential range of -0.85 to $-1.05 \mathrm{~V}$. As shown in Fig. $4 \mathrm{~b}$, the peak current increases greatly with changing potential from -0.85 to $-1.00 \mathrm{~V}$, probably due to the fact that $\mathrm{Co}^{2+}$ can be reduced more efficiently at more negative deposition potentials. Experiments also showed that the peak current decreased at a potential more negative than $-1.00 \mathrm{~V}$, and a higher background current was apparent which might be attributed to the co-hydrogen evolution at such negative potentials. Therefore, an optimum deposition potential of $-1.00 \mathrm{~V}$ was used in the following experiments.

\section{Effect of accumulation time}

The effect of the accumulation time on the peak current of $\mathrm{Co}^{2+}$ was investigated. The corresponding results are shown in Fig. 4c. The variation of the peak current is depicted with the accumulation time for $2 \mathrm{nM} \mathrm{Co}^{2+}$ in the range from 30 to $150 \mathrm{~s}$. The response current increases rapidly with the
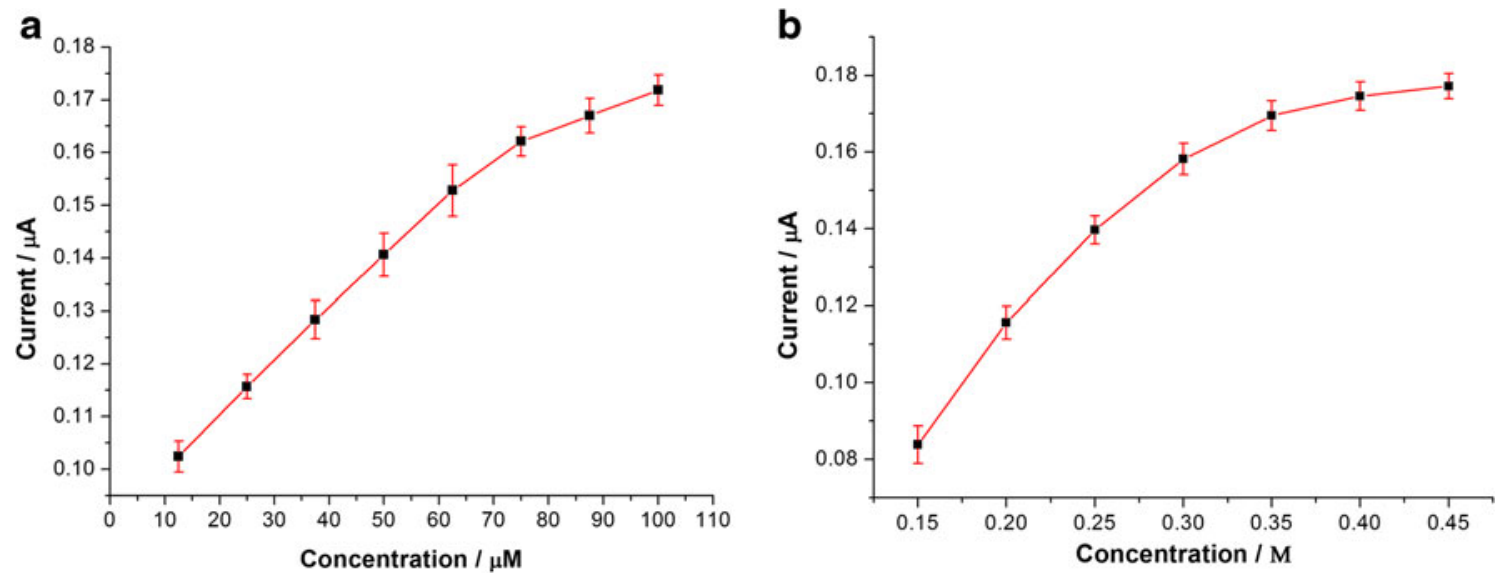

Fig. 3 Effect of varying a nioxime concentration and $\mathbf{b}$ nitrite concentration on the AdCSV sensitivity for $2 \mathrm{nM} \mathrm{Co}^{2+}$ at the $\mathrm{SnBiE}$. Accumulation potential, $-1.4 \mathrm{~V}$; accumulation time, $60 \mathrm{~s}$; equilibration time, $4 \mathrm{~s}$; increment potential of each step, $5 \mathrm{mV}$; pulse amplitude, $25 \mathrm{mV}$ 

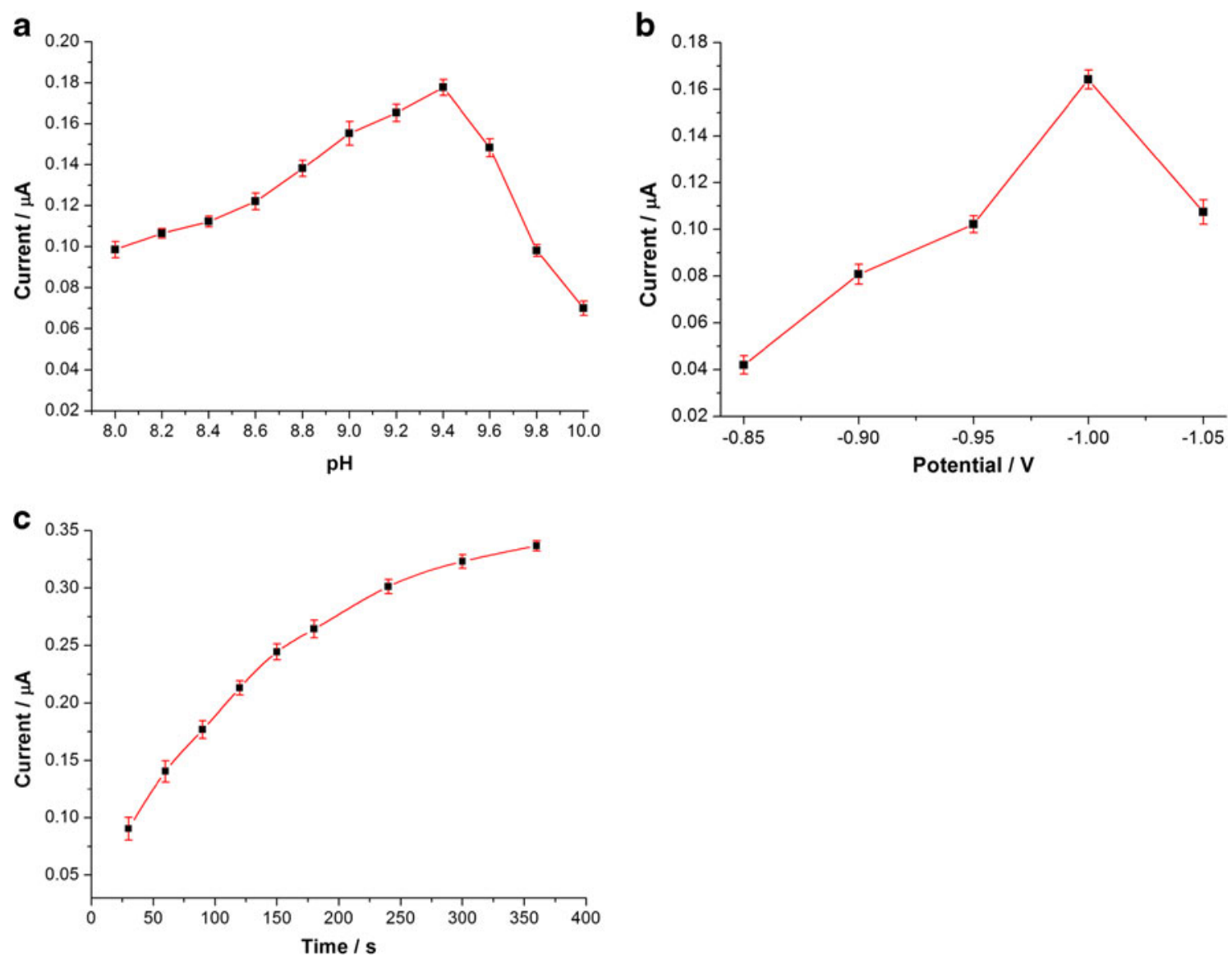

Fig. 4 Effect of varying a $\mathrm{pH}$ values of buffer solution, $\mathbf{b}$ accumulation potential, and $\mathbf{c}$ accumulation time on the stripping peak current of $2 \mathrm{nM} \mathrm{Co}{ }^{2+}$ at the SnBiE. Other conditions are the same as in Fig. 3

accumulation time up to $150 \mathrm{~s}$ and then increases slowly. Though a longer accumulation time can increase the amount of $\mathrm{Co}^{2+}$ on the electrode surface and improve the sensitivity of practical determination, a short analysis time of $60 \mathrm{~s}$ is sufficient for determination of $\mathrm{Co}^{2+}$ in tap water. Additionally, for determination of lower concentration of $\mathrm{Co}^{2+}$ in other matrixes, a prolonged accumulation time is recommended.

\section{Calibration curve}

The calibration curve of $\mathrm{Co}^{2+}$ determination at the $\mathrm{SnBiE}$ by using AdCSV is shown in Fig. 5. For a 60-s accumulation, a proportional relationship between the reduction peak current and the concentration of $\mathrm{Co}^{2+}$ was obtained in the range of 0.2 to $20 \mathrm{nM}$ by fitting the following regression equation:

$i_{p}=11.91+43.24 C, r=0.998$

where $i_{p}$ is the reduction peak current in $\mathrm{nA}$, and $C$ is the concentration of $\mathrm{Co}^{2+}$ in $\mathrm{nM}$. The sensitivity of the $\mathrm{SnBiE}$ to $\mathrm{Co}^{2+}$ is $43.24 \mathrm{nA} / \mathrm{nM}$. The detection limit was given by the equation $C_{L}=3 S_{\mathrm{b} 1} / S$, where $S_{\mathrm{b} 1}$ is the standard deviation of the blank measurements and $S$ is the sensitivity of the calibration graph. The detection limit of $\mathrm{Co}^{2+}$ for $60 \mathrm{~s}$ accumulation was calculated to be $44 \mathrm{pM}$, which is lower than that at hanging

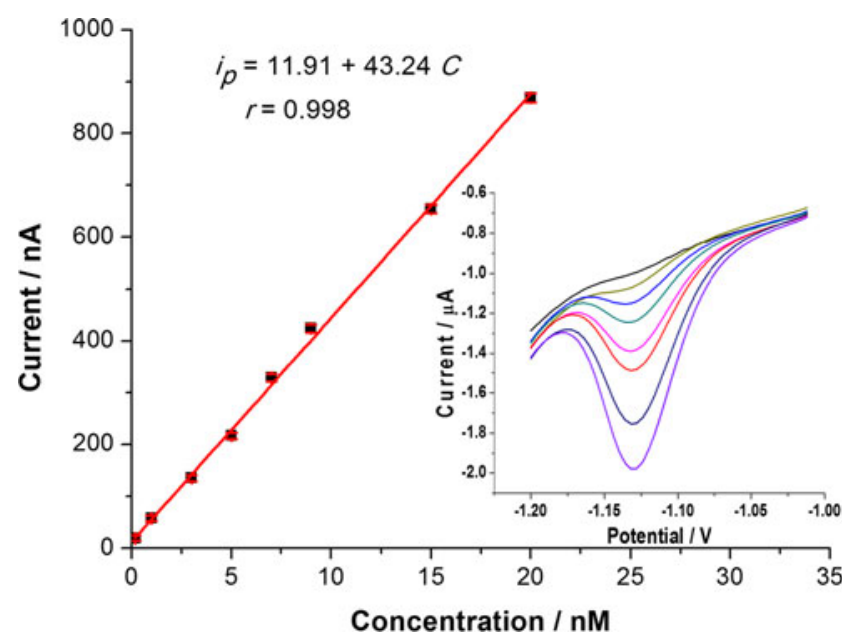

Fig. 5 Calibration curve of $\mathrm{Co}^{2+}$ at the $\mathrm{SnBiE}$. The concentrations of $\mathrm{Co}^{2+}$ for the inset curves are $0.2,1,3,5,7,9,15$, and $20 \mathrm{nM}$ from the bottom to the top, which are in the linear range. Other conditions are the same as in Fig. 3. (When not visible, error bars are smaller than the symbols) 
Table 2 The data for the application of various electrodes in the adsorptive stripping voltammetry of Co(II)

\begin{tabular}{|c|c|c|c|c|c|}
\hline Electrode type & Technique & $\begin{array}{l}\text { Complexing } \\
\text { agent }\end{array}$ & $\begin{array}{l}\text { Linear range } \\
(\mu \mathrm{g} / \mathrm{L})\end{array}$ & $\begin{array}{l}\text { Detection limit } \\
(\mu \mathrm{g} / \mathrm{L} \text {, dep. time }(\mathrm{s}))\end{array}$ & Ref. \\
\hline Hanging mercury drop electrode & SW-AdCSV & DMG & ND & $8 \mathrm{pM}\left(t_{\mathrm{acc}}=\mathrm{ND}\right)$ & [44] \\
\hline Hanging mercury drop electrode & DP-AdCSV & Nioxime & $0-3 \mathrm{nM}$ & $3 \mathrm{pM}\left(t_{\mathrm{acc}}=60 \mathrm{~s}\right)$ & [12] \\
\hline Hanging mercury drop electrode & DP-AdCSV & $\alpha$-furil dioxime & $0.5-40 \mathrm{nM}$ & $0.34 \mathrm{nM}\left(t_{\mathrm{acc}}=20 \mathrm{~s}\right)$ & [2] \\
\hline Hanging mercury drop electrode & DP-AdCSV & Pyrogallol red & $0-0.68 \mu \mathrm{M}$ & $0.34 \mathrm{nM}\left(t_{\mathrm{acc}}=60 \mathrm{~s}\right)$ & [16] \\
\hline Stationary mercury drop electrode & DP-AdCSV & Pyrogallol red & $0.08-4.75 \mu \mathrm{M}$ & $16.9 \mathrm{nM}\left(t_{\mathrm{acc}}=140 \mathrm{~s}\right)$ & [37] \\
\hline $\begin{array}{l}\text { Cylindrical silver-based renewable } \\
\text { amalgam film electrode }\end{array}$ & SW-AdCSV & DMG & $0.5-100 \mathrm{nM}$ & $100 \mathrm{pM}\left(t_{\mathrm{acc}}=60 \mathrm{~s}\right)$ & [13] \\
\hline $\begin{array}{l}\text { Cylindrical silver-based amalgam } \\
\text { film electrode }\end{array}$ & DP-AdCSV & $\begin{array}{l}\text { Cycloheksanedione } \\
\text { dioxime }\end{array}$ & $0.17-118 \mathrm{nM}$ & $58 \mathrm{pM}\left(t_{\mathrm{acc}}=60 \mathrm{~s}\right)$ & [38] \\
\hline $\begin{array}{l}\text { In situ plated bismuth film } \\
\text { gold electrode }\end{array}$ & SW-AdCSV & Nioxime & $0.5-10 \mathrm{nM}$ & $110 \mathrm{pM}\left(t_{\mathrm{acc}}=120 \mathrm{~s}\right)$ & [39] \\
\hline $\begin{array}{l}\text { In situ plated bismuth film } \\
\text { gold electrode }\end{array}$ & SW-AdCSV & DMG & $0.17-0.93 \mu \mathrm{M}$ & $1.0 \mathrm{nM}\left(t_{\mathrm{acc}}=120 \mathrm{~s}\right)$ & [40] \\
\hline $\begin{array}{l}\text { Sputtered bismuth film } \\
\text { on-chip electrode }\end{array}$ & SW-AdCSV & DMG & $\begin{array}{l}34-270 \mathrm{nM} \\
\quad\left(t_{\mathrm{acc}}=30 \mathrm{~s}\right)\end{array}$ & $1.5 \mathrm{nM}\left(t_{\mathrm{acc}}=90 \mathrm{~s}\right)$ & [41] \\
\hline $\begin{array}{l}\text { Ex situ plated bismuth film } \\
\text { glassy carbon electrode }\end{array}$ & DP-AdCSV & DMG & ND & $1.0 \mathrm{nM}\left(t_{\mathrm{acc}}=60 \mathrm{~s}\right)$ & [42] \\
\hline $\begin{array}{l}\text { Renewable bismuth bulk } \\
\text { annular band electrode }\end{array}$ & DP-AdCSV & DMG & $1-70 \mathrm{nM}$ & $300 \mathrm{pM}\left(t_{\mathrm{acc}}=30 \mathrm{~s}\right)$ & [24] \\
\hline $\begin{array}{l}\text { Solid bismuth disk } \\
\text { vibrating electrode }\end{array}$ & SW-AdCSV & DMG & Up to $0.6 \mu \mathrm{M}$ & $16.9 \mathrm{nM}\left(t_{\mathrm{acc}}=30 \mathrm{~s}\right)$ & [43] \\
\hline $\begin{array}{l}\text { In situ plated lead film } \\
\text { glassy carbon electrode }\end{array}$ & SW-AdCSV & DMG & $1-100 \mathrm{nM}$ & $280 \mathrm{pM}\left(t_{\mathrm{acc}}=120 \mathrm{~s}\right)$ & {$[28]$} \\
\hline $\begin{array}{l}\text { In situ plated lead film } \\
\text { glassy carbon electrode }\end{array}$ & CC-CAdSCP & DMG & $0.75-8 \mathrm{nM}$ & $0.4 \mathrm{nM}\left(t_{\mathrm{acc}}=210 \mathrm{~s}\right)$ & [9] \\
\hline $\begin{array}{l}\text { In situ plated lead film } \\
\text { screen-printed electrode }\end{array}$ & SW-AdCSV & DMG & $50-500 \mathrm{nM}$ & $5 \mathrm{nM}\left(t_{\mathrm{acc}}=90 \mathrm{~s}\right)$ & {$[27]$} \\
\hline $\begin{array}{l}\text { In situ lead film carbon } \\
\text { screen-printed electrode }\end{array}$ & SW-AdCSV & Nioxime & $0.5-210 \mathrm{nM}$ & $50 \mathrm{pM}\left(t_{\mathrm{acc}}=120 \mathrm{~s}\right)$ & [29] \\
\hline $\begin{array}{l}\text { In situ plated lead-copper } \\
\text { film electrode }\end{array}$ & SW-AdCSV & DMG & $\begin{array}{l}0.5-20 \mathrm{nM} \\
\quad\left(t_{\mathrm{acc}}=15 \mathrm{~s}\right)\end{array}$ & $\begin{array}{l}120 \mathrm{pM}\left(t_{\mathrm{acc}}=15 \mathrm{~s}\right) \\
10 \mathrm{pM}\left(t_{\mathrm{acc}}=180 \mathrm{~s}\right)\end{array}$ & [30] \\
\hline Tin-bismuth alloy electrode & DP-AdCSV & Nioxime & $0.2-20 \mathrm{nM}$ & $44 \mathrm{pM}\left(t_{\mathrm{acc}}=60 \mathrm{~s}\right)$ & This paper \\
\hline
\end{tabular}

$D M G$ dimethylglyoxime, $S W-A d C S V$ square wave adsorptive cathodic stripping voltammetry, $D P-A d C S V$ differential pulse adsorptive cathodic stripping voltammetry, $C C-C A d S C P$ catalytic adsorptive stripping chronopotentiometric

mercury drop electrode $[2,16]$, stationary mercury drop electrode [37], cylindrical silver-based renewable amalgam film electrode [13, 38], in situ and ex situ plated bismuth film electrode [39-42], solid bismuth disk vibrating electrode [43], in situ plated lead film glassy carbon electrode and screen-printed electrode $[9,27,28]$, and in situ plated leadcopper film electrode [30]. The data for the application of various electrodes in the AdCSV determination of $\mathrm{Co}^{2+}$ is show in Table 2.

Six SnBiEs for $2 \mathrm{nM}$ of $\mathrm{Co}^{2+}$ were estimated and the results revealed that the $\mathrm{SnBiE}$ had satisfactory reproducibility with a relative standard deviation of $3.5 \%$. Furthermore, to ensure the repeatability of the electrode, a series of seven repetitive measurements of $5 \mathrm{nM} \mathrm{Co}^{2+}$ with a relative standard deviation of $2.6 \%$ were obtained. As a new electrode with a high repeatability, $\mathrm{SnBiE}$ is a potential for the practical analysis.

\section{Study of interferences}

The effect of possible interfering species was studied by analyzing a standard solution $\left(2 \mathrm{nM} \mathrm{Co}^{2+}\right)$ to which amounts of interfering ions were added under the optimized conditions (Fig. 6). Interfering ions were added at different concentrations (max. 1000-fold) which are higher than the concentration of $\mathrm{Co}^{2+}$ until they produced a change of $\geq 5 \%$ of the initial height. The results show that more than a 1000 fold excess of $\mathrm{Ni}^{2+}, \mathrm{Cu}^{2+}, \mathrm{Mn}^{2+}, \mathrm{Zn}^{2+}, \mathrm{Pb}^{2+}, \mathrm{Cr}^{3+}, \mathrm{Fe}^{3+}, \mathrm{Ca}^{2+}$, and $\mathrm{Mg}^{2+}$ and less than 50 -fold $\mathrm{Cd}^{2+}$ have no influence on the peak current of $2 \mathrm{nMCo}^{2+}$. This was probably attributed to the

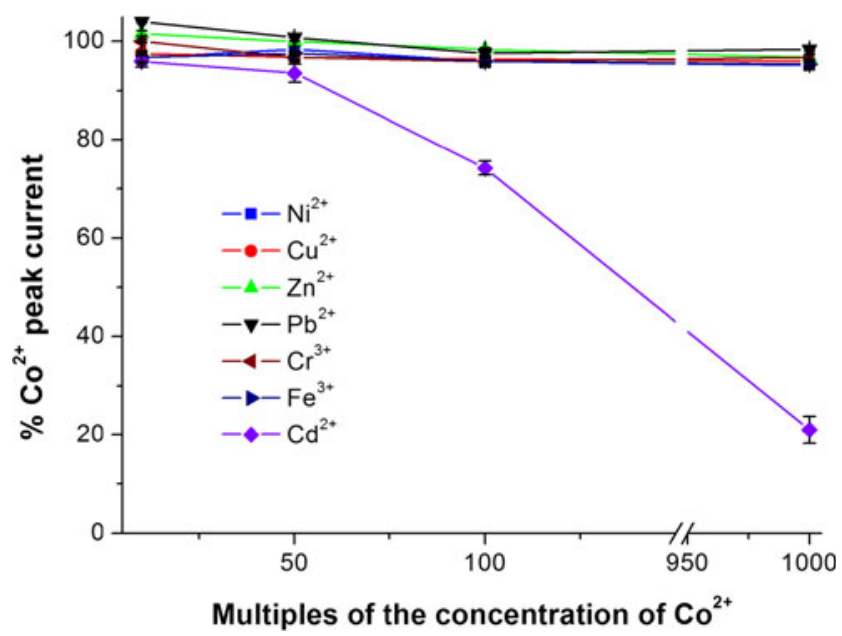

Fig. 6 Effect of possible interfering species on the $\mathrm{Co}^{2+}$ determination at the $\mathrm{SnBiE}$. Solution composition and other conditions are the same as in Fig. 3 


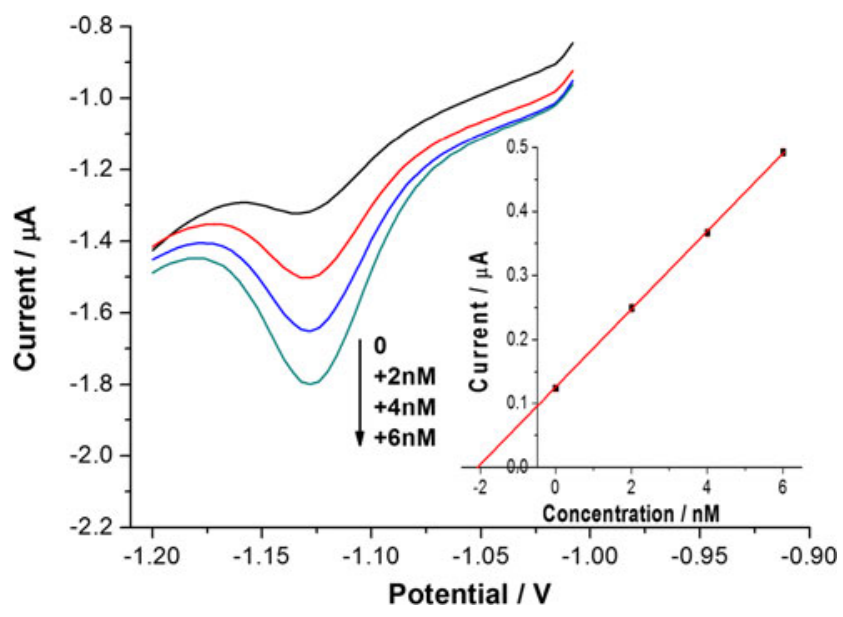

Fig. 7 Square wave voltammograms obtained in the course of $\mathrm{Co}^{2+}$ determination in tap water 2 . The addition concentrations of $\mathrm{Co}^{2+}$ from top to bottom are $0,2,4,6 \mathrm{nM}$. The inset is the fitted curve of $\mathrm{Co}^{2+}$ measurement obtained from standard addition. Other conditions are the same as in Fig. 3. (When not visible, error bars are smaller than the symbols)

selectivity of the complex ligand and the more negative accumulation potential $(-1.00 \mathrm{~V})$ which avoid effectively the interference of most metal ions as well as $\mathrm{Ni}^{2+}$. However, the effect of interferences on real samples analysis was eliminated effectively by using the standard addition method.

\section{Real sample analysis}

The accuracy of the method was estimated by determining cobalt in real water samples. For the performance of the proposed $\mathrm{SnBiE}$ in real sample analysis, the contents of $\mathrm{Co}^{2+}$ in tap water were analyzed by using the standard addition method. Figure 7 shows the AdCSV responses of tap water 2 at the $\mathrm{SnBiE}$. The voltammetric peak current of $\mathrm{Co}^{2+}$ in tap water can be detected at $\mathrm{SnBiE}$, which indicates the possibility of successful determination of $\mathrm{Co}^{2+}$ in real samples by using standard addition method. The concentration of $\mathrm{Co}^{2+}$ in real sample can be calculated from fitted curve (inset of Fig. 7). These results show that the $\mathrm{SnBiE}$ exhibits high sensitivity and good selectivity for the determination of $\mathrm{Co}^{2+}$ under the optimum experimental conditions. Additionally, in order to illustrate its accuracy in practical analysis, a comparison was carried out between the $\mathrm{SnBiE}$ and ICP-MS for detection of $\mathrm{Co}^{2+}$ in real

Table 3 Comparison of the SnBiE and ICP-MS for determination of $\mathrm{Co}^{2+}$ in real samples

\begin{tabular}{lll}
\hline Sample & Detected by SnBiE & Detected by ICP-MS \\
\hline Tap water 1 & $0.135 \pm 0.06(\mu \mathrm{g} / \mathrm{L})^{\mathrm{b}}$ & $0.161(\mu \mathrm{g} / \mathrm{L})$ \\
Tap water 2 & $0.114 \pm 0.05(\mu \mathrm{g} / \mathrm{L})$ & $0.122(\mu \mathrm{g} / \mathrm{L})$ \\
\hline
\end{tabular}

${ }^{a}$ Average value of three determinations \pm standard deviation

${ }^{\mathrm{b}}$ The concentration unit (nM) obtained by the $\mathrm{SnBiE}$ has been changed to $\mu \mathrm{g} / \mathrm{L}$ for consistency water samples (Table 3). As can be seen from Table 3, the results obtained from the $\mathrm{SnBiE}$ are consistently well with those results detected by ICP-MS, which indicates that the SnBiE can be used for determination of $\mathrm{Co}^{2+}$ in real samples.

\section{Conclusions}

In this paper, for the first time, we have presented the suitability of $\mathrm{SnBiE}$ for the determination of cobalt in water samples in combination with the AdCSV. Under optimized experimental conditions, excellent linear dynamic range $(0.2-20 \mathrm{nM})$ with a correlation coefficient of 0.998 and a detection limit of $44 \mathrm{pM}$ was obtained in connection with an accumulation time of $60 \mathrm{~s}$. It was found that the performance of the $\mathrm{SnBiE}$ for $\mathrm{Co}^{2+}$ analysis was better than that of the mercury, bismuth, lead, and lead-copper electrodes. Real water samples were determined, and the results obtained from the proposed SnBiE were in good agreement with those results detected by ICP-MS. A simple, convenient, and sensitive approach for the determination of $\mathrm{Co}^{2+}$ in natural water samples was provided without the sample pretreatment. Such an application of the $\mathrm{SnBiE}$ encourages the on-going efforts for on-site environmental monitoring of cobalt and other heavy metals in place of toxic mercury electrodes.

\section{References}

1. Vengellur A, LaPres J (2004) The role of hypoxia inducible factor $1 \alpha$ in cobalt chloride induced cell death in mouse embryonic fibroblasts. Toxicol Sci 82(2):638-646

2. Bobrowski A (2004) Catalytic adsorptive stripping voltammetric determination of cobalt and nickel as their $\alpha$-furil dioxime complexes. Electroanal 16(18):1536-1541

3. Barceloux DG, Barceloux D (1999) Cobalt. Clin Toxicol 37(2): 201-216

4. Cannizzaro V, Bowie AR, Sax A, Achterberg EP, Worsfold PJ (2000) Determination of cobalt and iron in estuarine and coastal waters using flow injection with chemiluminescence detection. Analyst 125(1):51-57

5. Gil RA, Gásquez JA, Olsina R, Martinez LD, Cerutti S (2008) Cloud point extraction for cobalt preconcentration with on-line phase separation in a knotted reactor followed by ETAAS determination in drinking waters. Talanta 76(3):669-673

6. Ghaedi M, Shokrollahi A, Ahmadi F, Rajabi H, Soylak M (2008) Cloud point extraction for the determination of copper, nickel and cobalt ions in environmental samples by flame atomic absorption spectrometry. J Hazard Mater 150(3):533-540

7. Bidabadi MS, Dadfarnia S, Shabani AMH (2009) Solidified floating organic drop microextraction (SFODME) for simultaneous separation/preconcentration and determination of cobalt and nickel by graphite furnace atomic absorption spectrometry (GFAAS). J Hazard Mater 166(1):291-296

8. Kong X, Jia Q, Zhou W (2007) Coupling on-line preconcentration by ion-exchange with microwave plasma torch-atomic emission 
spectrometry for the determination of cobalt and nickel. Microchem J 87(2):132-138

9. Bobrowski A, Królicka A, Putek M, Zarębski J, Antonatos N, Economou A (2013) Catalytic adsorptive stripping chronopotentiometry of Co (II)-DMG-bromate system at an in situ plated lead film electrode. Electroanal 25(10):2298-2304

10. Chaparro L, Ferrer L, Leal L, Cerdà V (2015) A multisyringe flowbased system for kinetic-catalytic determination of cobalt (II). Talanta 133:94-99

11. Nascimento DS, Insausti M, Band BSF, Lemos SG (2014) Simultaneous determination of $\mathrm{Cu}, \mathrm{Pb}, \mathrm{Cd}, \mathrm{Ni}, \mathrm{Co}$ and $\mathrm{Zn}$ in bioethanol fuel by adsorptive stripping voltammetry and multivariate linear regression. Fuel 137:172-178

12. Vega M, van den Berg CM (1997) Determination of cobalt in seawater by catalytic adsorptive cathodic stripping voltammetry. Anal Chem 69(5):874-881

13. Bobrowski A, Królicka A, Putek M, Zarębski J, Čelebić N, Guzsvány V (2013) Catalytic adsorptive stripping voltammetry of Co (II)-dioxime-bromate systems at renewable amalgam film electrode. Electrochim Acta 107:93-102

14. Bobrowski A (1989) Polarographic methods for ultratrace cobalt determination based on adsorption-catalytic effects in cobalt (II)dioxime-nitrite systems. Anal Chem 61(19):2178-2184

15. Rutyna I, Korolczuk M (2015) Determination of cobalt by adsorptive stripping voltammetry with double accumulation and stripping steps. Int J Environ Anal Chem 95(11):1042-1053

16. Rojas C, Arancibia V, Gómez M, Nagles E (2012) Adsorptive stripping voltammetric determination of cobalt in the presence of nickel and zinc using pyrogallol red as chelating agent. Int J Electrochem Sci 7:979-990

17. Li D, Jia J, Wang J (2010) A study on the electroanalytical performance of a bismuth film-coated and Nafion-coated glassy carbon electrode in alkaline solutions. Microchim Acta 169(3-4):221-225

18. Mikkelsen Ø, Schrøder KH (2000) Alloy electrodes with high hydrogen overvoltage for analytical use in voltammetry. Some preliminary results. Analyst 125(12):2163-2165

19. Wang J (2005) Stripping analysis at bismuth electrodes: a review. Electroanal 17(15-16):1341-1346

20. Wang J, Lu J, Hocevar SB, Farias PA, Ogorevc B (2000) Bismuthcoated carbon electrodes for anodic stripping voltammetry. Anal Chem 72(14):3218-3222

21. Kokkinos C, Economou A, Raptis I, Efstathiou CE (2008) Lithographically fabricated disposable bismuth-film electrodes for the trace determination of $\mathrm{Pb}$ (II) and Cd (II) by anodic stripping voltammetry. Electrochim Acta 53(16):5294-5299

22. Alves G, Magalhães JM, Soares HM (2011) Simultaneous determination of copper (II), lead (II) and zinc (II) at bismuth film electrode by multivariate calibration. Electroanal 23(6):1410-1417

23. Bučková M, Gründler P, Flechsig GU (2005) Adsorptive stripping voltammetric detection of daunomycin at a bismuth bulk electrode. Electroanal 17(5-6):440-444

24. Bas B, Wegiel K, Jedlinska K (2015) The renewable bismuth bulk annular band working electrode: fabrication and application in the adsorptive stripping voltammetric determination of nickel(II) and cobalt(II). Anal Chim Acta 881:44-53

25. Xiong CH, Luo HQ, Li NB (2010) A stannum/bismuth/poly (paminobenzene sulfonic acid) film electrode for measurement of Cd (II) using square wave anodic stripping voltammetry. J Electroanal Chem 651:19-23

26. Królicka A, Bobrowski A (2004) Bismuth film electrode for adsorptive stripping voltammetry-electrochemical and microscopic study. Electrochem Commun 6(2):99-104

27. Bobrowski A, Królicka A, Maczuga M, Zarębski J (2014) A novel screen-printed electrode modified with lead film for adsorptive stripping voltammetric determination of cobalt and nickel. Sens Actuators B: Chem 191:291-297

28. Korolczuk M, Tyszczuk K, Grabarczyk M (2005) Adsorptive stripping voltammetry of nickel and cobalt at in situ plated lead film electrode. Electrochem Commun 7(12):1185-1189

29. Bobrowski A, Królicka A, Maczuga M, Zarębski J (2015) Highly sensitive and selective adsorptive stripping voltammetric method employing a lead film screen-printed electrode for determination of cobalt as its nioximate complex. Electroanal. doi:10.1002/elan. 201500362

30. Grabarczyk M, Tyszczuk K, Korolczuk M (2006) Catalytic adsorptive stripping voltammetry of cobalt in the presence of dimethylglyoxime and nitrite at in situ plated lead-copper film electrode. Electroanal 18(1):70-76

31. Pan D, Zhang L, Zhuang J, Yin T, Qin W (2012) A novel tinbismuth alloy electrode for anodic stripping voltammetric determination of zinc. Microchim Acta 177(1-2):59-66

32. Pan D, Zhang L, Zhuang J, Lu W, Zhu R, Qin W (2012) New application of tin-bismuth alloy for electrochemical determination of cadmium. Mater Lett 68:472-474

33. Zhang L, Wang C-Z, Tang H-B, Wang L, Liu Y-S, Zhao Y-L, Chai Z-F, Shi W-Q (2015) Rapid determination of uranium in water samples by adsorptive cathodic stripping voltammetry using a tinbismuth alloy electrode. Electrochim Acta 174:925-932

34. Pauliukaitė R, Hočevar SB, Ogorevc B, Wang J (2004) Characterization and applications of a bismuth bulk electrode. Electroanal 16(9):719-723

35. Economou A (2005) Bismuth-film electrodes: recent developments and potentialities for electroanalysis. Trac-Trend Anal Chem 24(4): 334-340

36. Bobrowski A, Zarebski J (2000) Catalytic systems in adsorptive stripping voltammetry. Electroanal 12(15):1177-1186

37. Hasanpour F, Teimori H, Fouladgar M, Taei M (2013) Trace and selective determination of cobalt (II) in water and salt samples using cathode adsorptive stripping voltammetry in the presence of pyrogallol red. J Serb Chem Soc 78(5):717-724

38. Kapturski P, Bobrowski A (2008) The silver amalgam film electrode in catalytic adsorptive stripping voltammetric determination of cobalt and nickel. J Electroanal Chem 617(1):1-6

39. Rutyna I, Korolczuk M (2011) Catalytic adsorptive stripping voltammetry of cobalt in the presence of nitrite at an in situ plated bismuth film electrode. Electroanal 23(3):637-641

40. Mardegan A, Dal Borgo S, Scopece P, Moretto L, Hočevar S, Ugo P (2013) Simultaneous adsorptive cathodic stripping voltammetric determination of nickel (II) and cobalt (II) at an in situ bismuthmodified gold electrode. Electroanal 25(11):2471-2479

41. Kokkinos C, Economou A, Koupparis M (2009) Determination of trace cobalt (II) by adsorptive stripping voltammetry on disposable microfabricated electrochemical cells with integrated planar metalfilm electrodes. Talanta 77(3):1137-1142

42. Krolicka A, Bobrowski A, Kalcher K, Mocak J, Svancara I, Vytras K (2003) Study on catalytic adsorptive stripping voltammetry of trace cobalt at bismuth film electrodes. Electroanal 15(23-24): 1859-1863

43. Alves G, Magalhães JM, Soares HM (2013) Simultaneous determination of nickel and cobalt using a solid bismuth vibrating electrode by adsorptive cathodic stripping voltammetry. Electroanal 25(5): $1247-1255$

44. Zhang H, Wollast R, Vire J-C, Patriarche GJ (1989) Simultaneous determination of cobalt and nickel in sea water by adsorptive cathodic stripping square-wave voltammetry. Analyst 114(12):15971602 